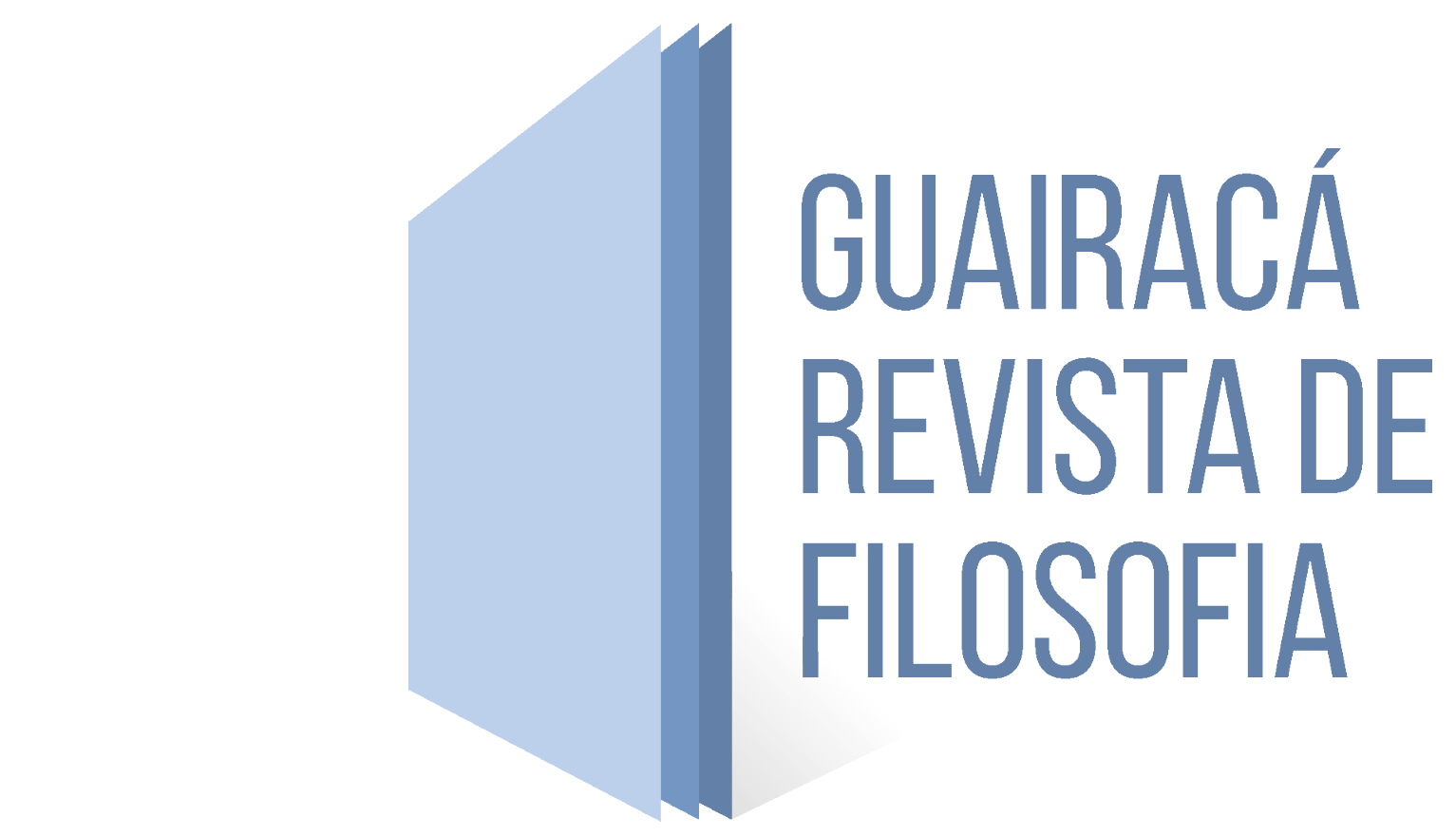

\title{
TEORIA DA AÇÃO EM KIERKEGAARD: REVISITANDO O ARTIGO DE PETER SIMONS
}

Resumo: Este artigo tem o objetivo de revisar as críticas e o resultado obtido por Peter Simons em seu artigo Kierkegaard's Theory of Action, de 1976, e dar uma nova resposta sobre a teoria da ação em Kierkegaard. Para tanto, o texto foi dividido em quatro partes: a primeira corresponde à introdução, que versa sobre o problema da teoria da ação na filosofia, revisão bibliográfica sobre o tema com referência a Kierkegaard, e o panorama desse conceito através de um exemplo dado pelo próprio filósofo; na segunda parte, é exposta a descrição da teoria da ação de Kierkegaard segundo Peter Simons, onde a dividimos em dez pontos interpretativos; na terceira, é feita a revisão de cinco desses pontos interpretativos de Simons e colocada nossas alternativas a eles; na quarta, apresentamos as conclusões. O principal resultado dessa pesquisa e reinterpretação do conceito de ação kierkegaardiano é o de que não podemos dizer que esse autor tenha uma teoria da ação por conta do contexto teórico em que ele desenvolveu esse conceito.

Palavras-chave: Teoria da ação. Kierkegaard. Peter Simons. Decisão. Pensador subjetivo.

1. Mestrando pelo Programa de Pós-Graduação em Filosofia-UNISINOS. Bolsista PROSUC-CAPES. E-mail: victormmanoel@gmail.com 


\section{THEORY OF ACTION IN KIERKEGAARD: REVISTTING PETER SIMONS' ARTICLE}

Abstract: This article aims to review the critiques and the obtained results by Peter Simons' 1976 article Kierkeggard's Theory of Action and give a new response about Kierkegaard's theory of action. For this purpose, the text has been divided into four parts: the first one corresponds to the introduction, that deals with the matter of the theory of action in philosophy, a bibliographic review about the issue with references to Kierkegaard, and the background of this concept throughout the example given by the philosopher himself; in the second part, it is showed the description of Kierkergaard's theory of action according to Peter Simons, which we have divided in ten interpretative points; in the third one a review for these five interpretative points is done and our alternatives are put to them; in the fourth one, we present our conclusions. The main result for this research and reinterpretation of the Kierkegaardian concept of action is that we cannot say that this author has a theory of action due the theoretical context in which he had developed this concept.

Key-words: Theory of Action. Kierkegaard. Peter Simons. Decision. Subjective thinker.

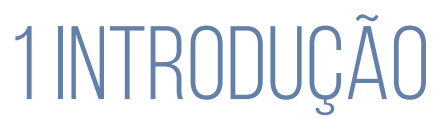

Não é desconhecido que um dos importantes problemas da filosofia seja o de determinar quando um sujeito, de fato, agiu ou não agiu. Essa questão vem à tona, sobretudo, quando precisamos atribuir responsabilidade a alguém por suas ações, pelas coisas que faz e, isso, com critérios objetivos, onde todos possam assentir sobre determinado caso. Dessa forma, podemos contextualizar a filosofia da ação dentro de duas grandes áreas da filosofia, a saber, a ética e a política (aqui, quando tratamos dos critérios de uma coerção legítima por parte do Estado, por exemplo).

A raiz do problema passa pelo dado de que os corpos, no mundo, se movimentam; mas concernente ao homem, certos movimentos parecem ter características diferentes uns dos outros, fazendo com que distingamos, por exemplo, entre uma simples atividade do corpo (como um espasmo) de um levantar de braços ${ }^{2}$. Surgem, daí, perguntas como: somos responsáveis pelo espasmo? E pelo 2. Como dizem George Wilson and Samuel Shpall (2012) no verbete Action da Stanford Encyclopedia of Philosophy (online): "If a person's head moves, she may or may not have moved her head, and, if she did move it, she may have actively performed the movement of her head or merely, by doing something else, caused a passive movement. And, if she performed the movement, she might have 
levantar do braço? Qual a diferença entre esses movimentos do corpo? Qual o papel da consciência na ação? É necessário que saibamos descrever o objetivo da ação ou os passos que estamos dando no decorrer da atividade? Todavia, é claro, isso é somente a ponta do iceberg; inúmeras outras variáveis e tipos de ações podem, e devem, ser analisadas quando levamos esse problema adiante. Posteriormente, como aponta Vicent Descombes (1995, p. 104), com a influência de Wittgenstein e o enfraquecimento das teorias da consciência (que ocuparam eminente lugar na filosofia do século XIX),

[...] la tâche principale d'une philosophie de l'action ne serait pas de se demander si notre comportement est plus qu'un simple événement physique (à savoir, une action intentionnelle). Elle serait, ici comme ailleurs, d'éclaircir le système des concepts qui nous servent quand nous parlons des réalités pratiques (ceux de but, de moyen, de résultat, d'échec et de succès, d'intention, de circonstances, de motif, d'excuse, de volontaire, de responsabilité, de mérite, etc.).

É possível observarmos, assim, uma evolução no tratamento do problema da ação, passando por diferentes focos e "necessidades".

Søren Kierkegaard (1813-1855), filósofo dinamarquês que tem uma série de escritos voltados à temática religiosa, escreveu, no Pós-Escrito Conclusivo não Científico às Migalhas Filosóficas ${ }^{3}$ (1846), aquilo que seria a sua definição mais explícita sobre a ação. Contudo, a pesquisa por esse conceito específico em Kierkegaard não parece ter chamado muito a atenção dos pesquisadores. Sequer encontramos um verbete dedicado a esse conceito no tomo I do volume XV da monumental coletânea Kierkegaard Research: Sources, Reception and Resources (2013) editada por Steven Emmanuel, William McDonald e Jon Stewart. O único trabalho, dedicado exclusivamente a esse tema, que encontramos, foi o de Peter Simons, intitulado Kierkegaard's Theory of Action, escrito há mais de 40 anos atrás (1976) - não que o tempo do artigo seja um problema, por si. Nesse artigo, Simons toma uma postura crítica do que seria a teoria da ação kierkegaardiana e, ao analisá-la, vai mostrando as suas fraquezas e incapacidades para dar respostas à perguntas legítimas que se têm na busca de uma teoria da ação.

De nossa parte, o que faremos nesse artigo será revisar algumas das interpretações que julgamos serem as mais importantes de Simons, a fim de vermos

done so intentionally or not. This short array of contrasts (and others like them) has motivated questions about the nature, variety, and identity of action."

3. Utilizaremos, aqui, a tradução de Álvaro Valls, feita em duas partes. A primeira parte, publicada em 2013, corresponde ao Pós-Escrito volume I, e a segunda parte, publicada em 2016, ao Pós-Escrito volume II. Em conjunto ao ano como indicação bibliográfica, indicaremos, também, seguindo o padrão internacional para referenciar Kierkegaard, o trecho selecionado no texto original contido VII volume da Søren Kierkegaards Skrifter (SKS7). 
se elas correspondem adequadamente ao texto kierkegaardiano, se ele chega a um resultado adequado e se temos alguma alternativa a sua interpretação.

Excetuando-se essa introdução - que ainda conta com o item 1.1, que pretende mostrar o exemplo emblemático do que seja a ação para Kierkegaard, servindo-nos, assim, também como introdução ao debate - dividimos nosso artigo em outras três partes: a primeira delas será a apresentação dos argumentos de Simons em seu artigo; a segunda consiste na nossa revisão de cinco desses pontos interpretativos feitos por Simons; e, depois, a terceira parte que conterá a nossa conclusão.

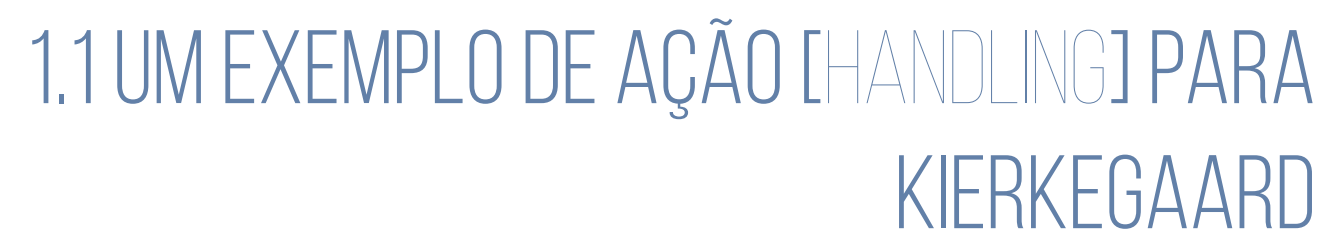

O nosso intento, agora, como dito acima, não é o de começarmos a explicar a teoria da ação kierkegaardiana, mas o de ganharmos a vantagem de situarmos a ideia que Kierkegaard tem desse conceito por meio de uma história que o próprio Simons usa contra ele. Esse exemplo, que ilustra a posição do filósofo, é o de uma pequena ficção relativa a uma das parábolas de Jesus contidas no Novo Testamento (Lucas 10: 25-37): a do Bom Samaritano. Eis como Kierkegaard a apresenta no PósEscrito:

\begin{abstract}
Quando o Levita passou ao largo do infeliz que fora assaltado por ladrões na estrada de Jericó a Jerusalém, talvez lhe ocorresse, quando ainda estava um pouco distante do infeliz, que seria de fato belo ajudar um sofredor; ele talvez até já tivesse pensado qual recompensa tal boa ação traz em si mesma; ele talvez cavalgasse mais lento por estar imerso em pensamentos; mas à medida que ia chegando mais perto, as dificuldades se mostraram, e ele passou ao largo. Agora ele decerto cavalgava ligeiro para ir embora depressa, para longe do pensamento da insegurança da estrada, para longe do pensamento da possível proximidade dos bandidos, e para longe do pensamento de quão facilmente o infeliz poderia confundi-lo com os bandidos que o largaram ali deitado. Ele, portanto, não agiu. Mas suponhamos que ao longo do caminho o arrependimento o trouxesse de volta, sem temer nem ladrões nem outras dificuldades, temendo apenas chegar tarde demais. Suponhamos que de fato chegasse tarde demais, dado que o bom samaritano já teria levado o sofredor para a hospedaria: ele, então, não agiu? Decerto que sim, e, contudo, ele não agiu no exterior. (2016, p. 56-57/ SKS7, p. 310-311).
\end{abstract}

De forma geral, sem nos aprofundarmos agora, a primeira noção que podemos extrair desse trecho é que os efeitos que produzimos no mundo efetivo não são o critério para determinarmos o que é uma ação. O que pode parecer peculiar é que, em ambas as situações narradas, temos o seguinte: o levita não fez nada, i.e., 
nos dois casos, ele não modificou o estado do mundo ajudando o homem caído. Por isso, a pergunta que fica é: como pode o mesmo "nada" ter qualidades diferentes, já que não interessa se o levita conseguiu realizar o que queria na segunda vez (que era dar auxílio)? A despeito disso, Kierkegaard afirma que ele agiu. Essa, por exemplo, será uma das críticas de Simons; mas que analisaremos em outro lugar.

\section{A TEORIA DA AÇÃO KIERKEGAARDIANA SEGUNDO SIMONS}

A partir de agora, iremos analisar um de dois movimentos que Simons faz em seu artigo Kierkegaard's Theory of Action; são eles: primeiro ele descreve como seria a teoria da ação kierkegaardiana a partir do Pós-Escrito (incluindo algumas referências a outras obras) e, em segundo, ele se propõe a confrontá-la com o problema visto de forma tradicional - embora essas duas partes não sejam divididas em seções, elas são perceptíveis na leitura porque demarcadas. Nesta seção, é de nosso interesse acompanhar apenas o primeiro movimento, apresentando seus pontos de interpretação para, posteriormente, virmos a revisar alguns deles.

Sigamos, pois, com a descrição.

O primeiro desses pontos de interpretação é sobre o próprio objetivo de Simons: "What I hope to do in this article is to take a detailed look at a very small part of Kierkegaard's work, considering it as a philosophical theory, and subjecting it to the close scrutiny that it deserves". (1976, p. 111). Isso nos faz atentarmos ao fato de que 1) é Simons quem faz da "pequena parte" uma teoria e 2) que mereça um exame extremamente detalhado [scrutiny]. Em conjunto, podemos identificar, também, como segundo ponto de interpretação a circunscrição da teoria e de sua análise a essa pequena parte mencionada, que Simons aponta como sendo duas páginas do Pós-Escrito ${ }^{4}$, embora ele reconheça a importância desse conceito de ação e de sua ligação com outros temas de seus escritos.

Dando continuidade à descrição, vemos que um terceiro ponto interpretativo de Simons está ao afirmar que a teoria da ação de Kierkegaard está ligada com suas outras teorias da escolha e do tempo (1976, p. 111). Simons admite que não está bem familiarizado com a última para pode falar dela, enquanto sobre a da escolha ele pode determinar a narrativa cronológica da ação, dividir a ação em fases, etc. Depois disso, como quarto ponto identificado por nós, Simons (1976, p. 112) apresenta o foco de Kierkegaard ao falar de um tipo particular de ação (denominado

4. "What Kierkegaard has to say explicitly and connectedly about the concept of action occupies a mere two pages of the Concluding Unscientific Postscript [...]". (1976, p. 111). Essas páginas encontramse em: 2016, p. 55-58/ SKS7, p. 309-312. 
por Simons de strictly personal action) e de suas condições ${ }^{5}$; porém, Simons também diz que Kierkegaard deveria ter especificado que é apenas desse tipo de ação que ele estava falando e não da ação como tal ${ }^{6}$. Para Simons, isso é um problema tendo em vista que as condições dadas por Kierkegaard para a ação são muito restritas, deixando de lado, ou não dando conta, de uma série de outras ações. Outro aspecto "limitado" das condições da ação está vinculado ao de não ser possível a avaliação da ação de terceiros, mesmo que Kierkegaard aponte, segundo Simons (1976, p. 112), que os critérios para uma avaliação ética sejam os dados por Jesus Cristo contidos nos Evangelhos.

O quinto ponto interpretativo de Simons está em sua atenção à relação, explorada naquela pequena parte, entre pensamento e ação. Aí, Kierkegaard nega duas alternativas do que seja a ação; a primeira é a de apenas pensar na ação, já que o conteúdo do pensamento é real, e a segunda de que a ação seja mudar algo no mundo sensível. Seguindo a citação onde consta o exemplo de Kierkegaard de que um pobre pode ser tão compassivo quanto alguém que doe um reino (2016, p. 56/ SKS7, p. 310), Simons aponta que Kierkegaard tem em mente apenas as ações que podem ser avaliadas moralmente, que se harmonizam àquelas condições restritas da ação; mas como podemos avaliar as ações de formas diferentes que a moral, Simons afirma que tal limitação posta por Kierkegaard acaba sendo perigosa para uma teoria da ação (1976, p. 113).

O sexto ponto interpretativo de Simons (1976, p. 113) é derivado da adequada observação de que, numa teoria da ação, o pensamento do indivíduo no momento da ação deve ser considerado como parte integrante da sua descrição, pois há diferença entre situações que acontecem com a intenção do sujeito (que costumamos chamar de 'ações') ou sem ela (que poderiam ser classificadas - uma parte delas, no mínimo - como 'acidentes'). Entretanto, para Simons, Kierkegaard não segue esse caminho natural ao descrever o pensamento como desinteressado ${ }^{7}$. Segundo ele, Kierkegaard faz isso no seguinte trecho: "Se é que deve haver uma diferença entre pensar e agir, então ela só pode ser sustentada em se atribuindo ao pensamento a possibilidade, o desinteresse, a objetividade-e à ação a subjetividade".

5. Narradas por Simons como: “[...] done by a single person, over an issue which concerns himself alone, typically, a vital moral or religious issue, and in which the action is preceded by a period of conscious deliberation, resulting in a conscious and deliberate choice of one alternative". (1976, p. 112).

6. Lemos essa crítica de Simons em suas seguintes palavras: “Kierkegaard might be taken as pointing out that this variety is only understood against the paradigm of the strictly personal action. If this were his position, it would be a stronger one than the one he in fact adopts, which is to treat the conditions as defining action itself. He assimilates features suggested by the restrictions into his account of action as such, to the detriment of the latter". (1976, p. 112).

7. "In particular the intention with which an action is performed must be included in any complete description of the action. Kierkegaard does not follow this seemingly natural way, though, because of his way of conceiving thought: [...]." (1976, p, 113). O restante desse excerto é a citação que usaremos no corpo do texto a seguir. 
(2016, p. 55-56/ SKS7, p. 309-310). Desse modo, o pensamento acabaria sendo indiferente para a ação porque tem a característica de ser desinteressado, ou seja, a ação, em Kierkegaard, poderia prescindir desse elemento já que o motivo dele ser levado em conta na avaliação de uma ação é o de se saber se o sujeito fez o que fez intencionalmente ('intenção', aqui, identificada, por Simons, com o pensamento). Mas como o pensamento é desinteressado, já se sabe a resposta ${ }^{8}$. Essa característica do pensamento, afirma Simons, força Kierkegaard a admitir um "pecado no pensamento" quando o indivíduo se depara com um dilema moral, que seria um exemplo de quando esse pensamento desinteressado se volta a algo concreto, que gera uma zona intermediária", onde o pensamento está “a ponto de ser perturbado" (mas que acaba não sendo, pois Kierkegaard não confirma essa hipótese, segundo Simons $\left.{ }^{10}\right)$. Outra falha dessa característica de desinteresse, além da confusão da "zona intermediária", levantada por Simons (e em consonância com a primeira crítica da indiferença) é a de que, na verdade, não podemos chamar de desinteressado o pensamento de intenção, isto é, aquele que está presente quando se quer fazer "isso" ou "aquilo", e também o pensamento de deliberação, presente quando se reflete sobre o dever ou não fazer algo, por mais que possamos ver as intenções e deliberações dos outros de forma desinteressada ${ }^{11}$ (em outras palavras, como Kierkegaard pode dizer que o pensamento é desinteressado se a gente pensa, na maioria das vezes, antes de fazer alguma coisa?).

Como solução desse problema da distinção e relação entre pensamento e ação, Simons julga pouco impressionante [little short of amazing] a dada por Kierkegaard e o cita: "A realidade efetiva não é a ação exterior, mas sim uma interioridade na qual o indivíduo suspende a possibilidade e se identifica com o que é pensado, a fim de existir nele. Isso é ação"12. (2016, p. 56/ SKS7, p. 310). Ou seja, 8. Simons não expressa, literalmente, essa crítica da indiferença, mas ela é deduzível porque o que ele reivindica é a análise do pensamento no momento da ação do sujeito, mas, como já sabemos que o pensamento, para Kierkegaard, é desinteressado, Kierkegaard não levaria ele em conta na sua descrição da ação.

9. 'twilight zone' na tradução usada por ele (não referenciada, apenas citada como a padrão); a frase inteira é esta: "But along this boundary there appears a twilight zone". Na tradução dos Hong, diferentemente, lê-se: "But now a confinium is readily apparent". (CUPI, p. 339). Em português, na tradução de Valls, "Mas agora mostra-se facilmente um confinium [lat.: fronteira, limite]". (2016, p. 56). E em dinamarquês: "Men nu viser der sig let et Confinium". (SKS7, p. 310). Mesmo as traduções não fazendo menção a uma "zona intermediária", optamos por tomar o termo, algumas vezes, para mantermos o diálogo com Simons.

10. "Despite this twilight zone, Kierkegaard will not actually admit that thought really is disturbed, only that it is 'on the way' to be disturbed". (1976, p. 113).

11. "In none of these cases could the thought be described as 'disinterested'. If a decision is impending for a certain person, any thought of that person on the possible courses of action open to him must be thought with a view to action". (1976, p. 113).

12. Observemos de que, na tradução utilizada por Simons, a primeira parte da frase consta como "The real action is not the external act [...]", ou seja, "The real action" corresponde, erroneamente, ao termo Virkeligheden utilizado por Kierkegaard, traduzido como "A realidade efetiva", por Valls, e "The actuality", pelos Hong. A diferença semântica que tais traduções ocasionam é considerável 
aos olhos de Simons (1976, p. 113) - e aqui poderíamos apontar um sétimo ponto interpretativo -, Kierkegaard, por estar tão ávido [so keen] em não fazer da ação exterior a "a ação real" [The real action], acaba por identificar a ação com a decisão, sendo a consequência disso, notavelmente, a não importância da ação exterior "[...] what we might normally think of as the enactment of the decison $[. . .]^{13 "}-$, ela tornando-se, agora, mero apêndice da decisão (1976, p. 114). A fim de ilustrar esse posicionamento de Kierkegaard, Simons utiliza aquela parábola modificada do bom samaritano, onde já vimos, de fato, a ação exterior não contar como critério.

Ao seguirmos a sua descrição, vemos que o oitavo ponto interpretativo está na observação (SIMONS, 1976, p. 114) de que Kierkegaard é consciente da distinção entre deliberação e intenção [intention, or having-decided] ao falar de uma dupla tarefa do sujeito: pensar cada possibilidade (deliberação), e se decidir, fazendo com que outras deliberações sejam desnecessárias ${ }^{14}$.

O nono ponto interpretativo se dá quando Simons (1976, p. 114115) observa que o que é decidido é o mesmo que foi previamente pensado, fazendo com que a diferença entre pensamento e ação seja apenas formal e não de conteúdo ${ }^{15}$ - e por 'forma', aqui, entende-se 'interesse'. Para Simons, isso faz com que Kierkegaard admita na intenção (ou decisão) algo mais que a possibilidade de ação - como é o caso da deliberação - porque ele primeiro descreveu o pensamento como desinteressado, mas vê interesse na intenção e, por isso, a toma como ação; porém, mesmo depois de identificar ação e decisão, ele admite (ou admite pela metade [or half-admit]) a zona intermediária, pois, mesmo os resultados da deliberação não são puramente contemplativos, mas também dizem respeito diretamente ao sujeito.

O décimo ponto interpretativo de Simons está no rastreamento que ele faz para a divisão operada por Kierkegaard entre interno e externo com respeito à ação (1976, p. 115-116), que, no Pós-Escrito, parece ocorrer por causa das categorias de possibilidade e de pensamento. Assim, ele vai ao $\mathrm{Ou}-\mathrm{Ou}$ (1843), para mostrar uma aceitação de Kierkegaard da categoria de necessidade história para o mundo (influenciada por Hegel) em contrapartida da liberdade individual; isso faz,

dada a profundidade que o conceito de Virkelighed alcança nesse estágio do livro - onde é identificado com a subjetividade, perdendo, em muito, apenas como "A ação real" (ainda mais prejudicado com a restringida perspectiva de Simons). É claro que, no final da passagem, Kierkegaard acaba identificando a efetividade com a ação e, com isso, uma certa ideia ou noção de 'ação real' (no sentido de: a ação verdadeira) poderia ser entendida, mas isso não diminui a perda da identificação de Kierkegaard entre dois termos diferentes, i.e., entre efetividade e ação, que tem, por trás dela, o avanço teórico sobre o ético.

13. SIMONS, 1976, p. 114.

14. Vide nota de rodapé em 2016, p. 58/ SKS7, p. 311.

15. O que lemos em 2016, p. 57/ SKS7, p. 311. 
salienta Simons, com que o indivíduo tenha uma dupla existência: a vida interna ou da liberdade, e a vida entre os outros corpos, submetida a lei de necessidade histórica. A saída, assim, para a conciliação entre a sua visão (de Kierkegaard) e a de Hegel, é dividir a ação em dois componentes: o interno e o externo ${ }^{16}$, um sobre o qual o sujeito tem controle, e o outro sobre o qual o sujeito não tem, ou tem pouco. Mas para Simons, em Temor e Tremor (1843), Kierkegaard parece ter acabado com todo o controle do sujeito sobre o componente externo, pois os dois estariam aleatoriamente $\operatorname{conectados}^{17}$. Porém, quando Kierkegaard escreve as Migalhas Filosóficas (1844), ele faz uma crítica à doutrina da necessidade histórica, mas que acaba por transferir o controle do mundo, que estava no processo de necessidade história, para Deus ${ }^{18}$ - que parece indicar que Kierkegaard assume um certo tipo de ocasionalismo (1976, p. 117); o ponto é que o sujeito não pode fazer realmente nada para mudar a efetividade do mundo, não está em suas mãos esse poder. O resultado disso é: a razão para a teoria da ação de Kierkegaard ser truncada é ético-religiosa, que separa as características que são relevantes ou não para a vida eterna da pessoa, sendo o indivíduo responsável pelas primeiras e não pelas segundas (o que leva à distinção interno-externo). Diz Simons (1976, p. 116):

Thus the individual is deemed responsible for the decisions he makes in his thinking, since his soul will survive death, but he is not deemed responsible for the movements of his body, which is something merely temporal and "external".

De forma geral, concluirá Simons (1976, p. 117) após a investigação, “[...] his philosophy of action is shaped by his metaphysics, and forms part of it".

Depois desses pontos, aos quais Simons já vai mostrando alguns problemas, ele começa aquele segundo movimento, que já mencionamos e afirmamos seu não tratamento aqui, de mostrar como a descrição oferecida por Kierkegaard a respeito da ação é insuficiente em dar respostas a outros problemas, além de conseguir apontar outras falhas suas, inclusive pela falta do uso de certos termos, como o 'tentar', por exemplo (1976, p. 118).

16. "Each individual therefore has a 'dual existence', an inward life which is free, and life as a body among other bodies, which is subject to the law of historical necessity. This solution is forced upon Kierkegaard at this early stage in his writings by the acceptance of the Hegelian account of history, while he also wishes to maintain that the individual can act freely [...]". (1976, p. 115).

17. "The individual's control over the affairs of the world has now completely gone, because where the connection between my resolutions and what happens is a purely random one, I have no control at all. The two components of an individual's action are thus seen as only randomly connected, which is to say that the individual exercises no control over the 'external' component". (1976, p. 116). 18. "The critique in the Fragments has affected Kierkegaard's position in that control of the affairs of the external world is transferred from the process of historical necessity to God, who attaches what result He pleases to the strivings of the individual". (1976, p. 116). 
Por isso, passemos, agora, ao nosso próximo passo, que será o de examinar mais de perto algumas dessas interpretações feitas por Simons.

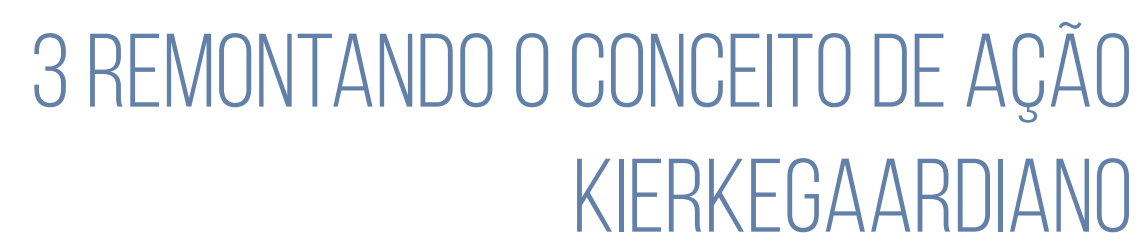

Nesta seção, como adiantado, iremos discutir algumas das interpretações acima que Simons fez sobre a ação em Kierkegaard a partir de sua leitura do Pós-Escrito. Dessas interpretações, selecionamos cinco, que nos pareceram equivocadas, para tratarmos diretamente. À medida com que as formos reapresentando, mostrando quais foram selecionadas, iremos, também, dando o nosso parecer sobre elas e uma alternativa interpretativa. Conforme julgamos, especialmente nessas interpretações de Simons, há um desvio que pretendemos corrigir e, assim, chegarmos a uma conclusão diferente tanto sobre o conceito de ação quanto sobre a teoria da ação kierkegaardiana - mesmo que, sobre essa última, mais radical.

Passemos à análise.

O primeiro erro interpretativo, que pensamos Simons ter cometido, é o de circunscrever o que Kierkegaard fala sobre a ação em apenas duas páginas do Pós-Escrito, precisamente aquelas onde se encontra o exemplo do levita arrependido, que na SKS7 estão entre às 309-312. Essa leitura reduzida é um erro porque, como colocamos o conceito de 'ação' dentro do campo da ética (dentro do qual Simons também quer analisar ${ }^{19}$ ), ao observarmos o contexto em que essas duas páginas estão localizadas, de pronto vemos que fazem parte de um assunto que perpassa, no mínimo, 40 páginas do Pós-Escrito ${ }^{20}$, i.e., os dois parágrafos do terceiro capítulo da seção dois da segunda parte - no tratamento direto da subjetividade, do existir e da ética. Seu foco de análise, portanto, já se apresenta como uma limitação; limitação, essa, que, naturalmente, tem a desvantagem de deixar de lado importantes distinções que Kierkegaard faz, o que acaba levandolhe a novos enganos. Por exemplo, embora Simons esteja correto ao afirmar que Kierkegaard foque sua atenção em apenas um tipo particular de ação (ao qual chamou - pensamos nós que adequadamente - de ação estritamente pessoal), ele também diz, como já vimos, que Kierkegaard deveria ter especificado que

19. 1976, p. 111.

20. 2016, p. 13-60/ SKS7, p. 275-314. 
é apenas desse tipo de ação que estava falando e não da ação como tal ${ }^{21}$. Para Simons, isso é um problema tendo em vista que as condições para $a$ ação, segundo a definição de Kierkegaard, são muito restritas, deixando de fora um conjunto de outras ações. Porém, é nesse ponto que encontramos outro erro interpretativo seu, i.e., não perceber que Kierkegaard distinguiu dois tipos, no mínimo, de ações e que estava a falar de apenas um.

A evidência textual que encontramos localiza-se fora daquelas duas páginas analisadas por ele:

Idolatrar esse puro pensar, sem nada mais, como o mais elevado, mostra que o pensador jamais existiu qua ser humano, que ele, entre outras coisas, no sentido eminente jamais agiu - não quero dizer com referência a realizações, mas com referência à interioridade. Mas agir em sentido eminente é algo que pertence essencialmente ao existir qua ser humano; (2016, p. 16/ SKS7, p. 277).

Aqui nessa passagem, podemos ver que Kierkegaard distingue explicitamente entre 'agir no sentido eminente' [at handle $i$ eminent Forstand], que tem a ver com a interioridade [Inderlighed], daquelas que são ações comuns, que ele chama de 'realizações' [Bedrift]. Essa falha interpretativa é de suma importância, pois, se a seguíssemos, acertadamente qualquer descrição que Kierkegaard fizesse da ação em sentido eminente poderia valer também para as meras realizações, ou seja, a partir de uma descrição do que é a ação se colocaria todos os demais tipos de ação. Passo que, segundo constatamos com o trecho selecionado acima, Kierkegaard, conscientemente, não dá. A esse respeito, assim, poderíamos chamar de ação [no sentido] forte a que Kierkegaard denominou de 'eminente', e de ação [no sentido] fraca a denominada de 'realizações'.

O terceiro erro interpretativo, que julgamos Simons ter cometido, diz respeito às consequências tiradas por ele a partir da caracterização feita por Kierkegaard do pensamento como desinteressado, a saber, duas consequências advindas de um mesmo ponto de partida: da identificação do pensamento como desinteressado, Simons chega ao "estranho" contato entre ação e pensamento (que, mesmo desinteressado, sofre um "pecado"22) e a irrelevância da ação exterior por colocar a ação apenas no domínio da decisão (ou seja, Kierkegaard põe uma diferença entre pensamento e ação; o pensamento é desinteressado, e a ação é subjetiva, i.e., interessada e interna; sendo subjetiva, assim, não é a ação externa que determina a

21. Relembrando: "Kierkegaard might be taken as pointing out that this variety is only understood against the paradigm of the strictly personal action. If this were his position, it would be a stronger one than the one he in fact adopts, which is to treat the conditions as defining action itself. He assimilates features suggested by the restrictions into his account of action as such, to the detriment of the latter". (1976, p. 112).

22. Além disso, recordemos que essa caracterização de desinteresse do pensamento leva Simons a pensar que Kierkegaard não dá importância para o pensamento na descrição da ação. 
ação, por isso que ela é irrelevante - ação externa que deveria estar conectada a um pensamento/intenção do sujeito, mas que não está por ele ser desinteressado, a não ser na "zona intermediária”). São esses dois resultados que iremos questionar por meio do erro interpretativo do desinteresse do pensamento.

Assim, nosso primeiro passo deve ser o de esclarecer que, para Kierkegaard, não há apenas essa definição, e até conotação, de desinteresse do pensamento; a situação não é, necessariamente, "pensamento, ergo, desinteresse" - se ele a faz nesse momento, deve haver um motivo que consigamos identificar sem arbitrariedade. Dessa forma, é preciso trazermos à tona a distinção de "pensamentos" feita por Kierkegaard - e isso julgamos poder fazer com uma única citação bem explícita quanto a isso:

Enquanto o pensamento objetivo é indiferente quanto ao sujeito que pensa e à sua
existência, o pensador subjetivo está, como existente, essencialmente interessado em
seu próprio pensamento, está existindo nele. Por isso, seu pensamento tem outro tipo
de reflexão, ou seja, o da interioridade, da posse, pelo qual ele pertence ao sujeito e
a ninguém mais. Enquanto o pensamento objetivo investe tudo no resultado e leva
toda a humanidade a trapacear, copiando e repetindo de cor o resultado e a resposta,
o pensamento subjetivo investe tudo no devir e omite o resultado, em parte porque
este justamente pertence a ele, já que ele possui o caminho, e em parte porque ele,
como existente, está continuamente no devir, como todo ser humano que não se
deixou enganar para tornar-se objetivo, para se converter, de modo não humano, na
especulação. (2013, p. $76 / S K S 7$, p. 73 ).

A distinção que queremos apontar encontra-se sob a nomenclatura de "pensamento objetivo" ou, ojá visto, "desinteressado" e "pensamento subjetivo", que seria o "interessado". Mas, mais precisamente, devemos notar que o que diferencia os dois é a reflexão, i.e., o tipo de reflexão que, por sua vez, é operada pelo sujeito que pensa. Ou seja, o sujeito pode refletir objetivamente ou subjetivamente, pois ele é ou um pensador objetivo ou um pensador subjetivo - talvez essa observação seja suficiente para mostrar um outro aspecto do pensamento, i.e., quando relacionado com aquele que o pensa.

Isso posto, nos parece surgir, no mínimo, duas alternativas de consideração do pensamento - que seriam correspondentes, se estivermos corretos, às duas maneiras com que Kierkegaard se refere a ele: uma enquanto vista nele mesmo, e outra vista em relação ao indivíduo que o pensa, ou seja, o pensamento enquanto algo universal (o pensamento por ele mesmo), e enquanto algo pensado, particular ("o meu pensamento"). Ao primeiro uso, podemos identificar que Kierkegaard oferece determinações ontológicas e modais como realidade e possibilidade ${ }^{23}$, e que ele está, frequentemente, as relacionado em oposição à efetividade/ser. 23. Por exemplo, Kierkegaard diz que a ideia tem vida eterna ao se referir à "vida eterna da ideia" [Ideens evige Liv] (2016, p. 45/ SKS7, p. 301) e que o abstrato tem realidade [Realitet] (2016, p. 46/ SKS7, p. 301). A possibilidade está ligada a essa realidade - possível porque não é efetivo. 
Ao segundo uso, no qual o pensamento é visto como um produto do sujeito, aí Kierkegaard pode oferecer, em conjunto das primeiras determinações, outras como subjetivo e objetivo, interessado e desinteressado. Essas últimas, obviamente, estão conectadas à subjetividade (basta lembrarmos dos dois tipos de pensadores, acima comentados, e seus tipos de reflexão). Mas Kierkegaard, naquela passagem utilizada por Simons ${ }^{24}$, descreve o pensamento [Tænkningen] como desinteressado e objetivo [respectivamente: Interesseløsheden e Objektiviteten] (características do pensamento que devem ser vistas, seguindo nossa interpretação, em relação ao sujeito que o pensa e não dele nele mesmo); como isso? A hipótese mais aceitável é que Kierkegaard o descreva assim por conta da ausência da subjetividade no pensamento nele mesmo, visto de forma universal, do que por qualquer noção pejorativa, i.e., o pensamento, no fundo, é algo neutro e que ganha algum tipo de qualificação apenas quando pensado pelo sujeito. Por exemplo, não é uma descrição negativa do pensamento determiná-lo como desinteressado e objetivo (isso é natural já que, em sua universalidade, não há interesse e nem subjetividade ${ }^{25}$, $\log$, a única alternativa é chamá-lo de desinteressado e objetivo), ao contrário do que seria qualificar o do pensador (o sujeito pensante, que tem subjetividade) de desinteressado e objetivo, pois isso, para Kierkegaard, significa que aquele que pensa está, de alguma forma, despreocupado com a própria existência - sendo o oposto dessa posição, o pensador subjetivo. Assim, é próprio de um pensamento, no sentido universal, ser desinteressado e objetivo - como um axioma geométrico, por exemplo -, porque ele não tem subjetividade e nem se direciona à subjetividade, ou também poderíamos dizer, a um campo que não lhe pertence ${ }^{26}$.

Onde podemos chegar com essa distinção: que o pensamento - um elemento neutro que é desinteressado apenas por não ter subjetividade nele mesmo (i.e., $o$ pensamento não é um indivíduo, um Selv) - pode sofrer (ou não) uma mudança qualitativa quando pensado pelo sujeito, isto é: o indivíduo pode continuar mantendo, com sua reflexão, o status objetivo do pensamento (que é não ligando-o à subjetividade, focando no resultado, em algo fora de si) ou mudá-lo para o subjetivo (quando o interesse está presente ou quando o sujeito está pensando com interesse em si mesmo). - Todavia, é justo notarmos que, tecnicamente, segundo Kierkegaard, somente é lícita essa mudança qualitativa, operada pelo tipo de reflexão do sujeito,

24. "[...] atribuindo ao pensamento a possibilidade, o desinteresse, a objetividade [...]". (2016, p. 56/ SKS7, p. 309).

25. Seria similar a dizer: "minha mesa é desinteressada"; isso é obvio, e o é exatamente por não poder ser o contrário. É mais uma definição por impossibilidade do contrário do que por alternativa.

26. O resultado dessas "trocas de campos" pode ser um problema porque: o pensamento que, legitimamente, pertença ao campo objetivo de pesquisa, indo parar no campo subjetivo, pode virar subjetivismo (i.e., quando a subjetividade altera a legítima objetividade); e o pensamento subjetivo, indo parar no campo objetivo, pode se tornar, entre outras coisas, autoritarismo, falsidade e irrelevância. 
em assuntos da ética e da religião, pois são nesses temas onde a verdade subjetiva do pensador subjetivo tem validade ${ }^{27}$ (validade representada pelo interesse subjetivo) ${ }^{28}$.

Dessa forma, vemos que não é um problema, como Simons julga, que Kierkegaard tenha definido o pensamento como desinteressado dada a possibilidade de mudança qualitativa desse pensamento operada pelo sujeito quando reflete sobre assuntos da ética, como o é o agir. Ou seja, o fato de o pensamento ser descrito como desinteressado em sua forma universal, não significa que ele, ao ser pensado, não possa ser subjetivado e ter importância na descrição da ação do sujeito.

Agora que já tratamos um pouco da distinção dos pensamentos (enquanto universal e particular) e do como atribuí-lo desinteresse, vejamos por queKierkegaard põe a diferença entre o pensamento e a ação, e como o sujeito entra nessa relação (aparentemente desconsiderado por Simons, já que ele tratou do pensamento enquanto universal sem se dar conta daquela mudança qualitativa, fazendo com que o sujeito pense desinteressadamente toda vez que pense - a não ser naquela zona intermediária). Depois disso, poderemos ver o que significa a admissão de Kierkegaard daquele "pecado no pensamento".

Para isso, teremos que utilizar e analisar um bom pedaço do parágrafo onde Kierkegaard aborda a ação:

Se o pensado fosse realidade efetiva, então aquilo que fosse pensado com a elaboração mais perfeita possível, quando eu ainda não tivesse agido, já seria a ação. Deste modo, não haveria absolutamente nenhuma ação, mas o [elemento] intelectual engoliria o ético. Que eu deva ser da opinião de que é o exterior o que faz da ação, a ação, é uma tolice; e, por outro lado, querer mostrar o quão ética é a intelectualidade, que esta até transforma pensamento em ação, é um sofisma culpado de uma duplicidade no uso da palavra: "pensar". Se é que deve haver uma diferença entre pensar e agir, então ela só pode ser sustentada em se atribuindo ao pensamento a possibilidade, o desinteresse, a objetividade - e à ação a subjetividade. Mas agora mostra-se facilmente um confinium [lat.: fronteira, limite]. Quando assim eu penso que hei de fazer isto ou aquilo, este pensamento por certo ainda não é uma ação e é qualitativamente diferente disso por toda a eternidade, mas ele é, contudo, uma possibilidade na qual já se reflete o interesse da realidade efetiva e da ação. Por isso, desinteresse e objetividade estão a ponto de ser perturbados, porque a efetividade e a responsabilidade querem apoderar-se deles. (Dá-se assim um pecado no pensamento.) - A realidade efetiva não é a ação exterior, mas sim uma interioridade na qual o indivíduo suspende a possibilidade e se identifica com o que é pensado, a fim de existir nele. Isso é ação. (2016, p. 55-56/ SKS7, p. 309-310).

O que Kierkegaard está fazendo aí, nitidamente, é nos dando a sua própria definição de ação. Para tanto, busca, de início, mostrar o que ela não é. Sua negação passa por duas alternativas: 1) o ato de pensar na ação e 2) tê-la feito exteriormente. A importância da primeira sentença do trecho acima pode parecer questionável 27. Vide 2013, p. 207-210/ SKS7, p. 180-182.

28. Voltaremos a falar desse ponto a seguir. 
dada a sua evidência, mas ela está de acordo com todo o segundo parágrafo do capítulo três do Pós-Escrito. Kierkegaard, até chegar aí, tratou, em muitas linhas, de questões ontológicas e, principalmente, elas frente ao ético: qual, por exemplo, a relevância do pensamento e da efetividade, se o ser é superior ao pensar, entre outras. Essas discussões são para responder àqueles ${ }^{29}$ que dão preponderância ao pensar, que acreditam que ele, de forma pura, pode dar conta da efetividade (que incluiria uma ética pouco tratada, senão nunca, ou com soluções objetivas). Como Kierkegaard não compartilha dessa perspectiva, ele vai negar esse "poder" do pensamento tanto no nível ontológico quanto - ou mais fortemente - no ético. Por isso, pelo contexto, a primeira negação - que pode ser expressa, também, em outras palavras: "se o pensamento não é efetividade (questão de fundo ontológico), quando eu penso numa ação não significa que eu tenha agido (questão de fundo ético)". Depois disso, Kierkegaard igualmente nega que o critério da ação seja a ação externa; ou seja, ter feito algo no mundo não significa ter agido (o que também parece estranho). O que é, então, a ação, já que nem o exterior a determina? Se a ação exterior não é a ação, ela é algo interno; porém, pensar também é algo interno. Assim, como diferenciar o pensamento da ação já que ambos estão no interior do sujeito? Diz Kierkegaard (2016, p. 55-56/ SKS7, p. 309-310): “Se é que deve haver uma diferença entre pensar e agir, então ela só pode ser sustentada em se atribuindo ao pensamento a possibilidade, o desinteresse, a objetividade - e à ação a subjetividade". Ou seja, quando Kierkegaard coloca essa diferença, vista como problemática por Simons, o que ele está fazendo é apresentando um elemento de distinção, ou melhor, um critério para a ação: a subjetividade. Isso mostra, antes de tudo, que aqueles candidatos à ação, i.e., o pensar e o agir exteriormente, são atividades que podem acontecer sem um acompanhamento da subjetividade - só agir no exterior não é ação; só pensar, mesmo que no interior, não é ação; sem subjetividade, sem ação. Porém, observemos o seguinte nessa passagem: mesmo que Kierkegaard tenha feito uma definição ontológica do pensamento [Tænkningen] ao dizer que ele é possível, desinteressado e objetivo (recordando do motivo pelo qual ele pode dizer os dois últimos ontologicamente), não faria nenhum sentido, ao distingui-lo $d a$ ação, não ter presente que a função dessa separação é com relação ao sujeito que pensa e não para com o próprio pensamento (que seria de uma obviedade desnecessária), i.e., a relação mais sensata é a de saber qual a diferença quando o sujeito pensa ou quando o sujeito age, e não meramente definir o pensamento enquanto tal, embora suas qualificações sejam as pertinentes para a distinção ${ }^{30}$. Ao que nos parece, a função dessa diferença

29. Em grande parte, para dizer o mínimo por conta da delicada relação Kierkegaard-Hegelhegelianos, seus contemporâneos hegeliano-dinamarqueses.

30. Talvez, uma das mais claras evidências dessa nossa interpretação seja a posterior passagem onde Kierkegaard (2016, p. 57/ SKS7, p. 311) diz: “Entre a ação pensada e a ação real, entre possibilidade e realidade efetiva, não há, talvez, nenhuma diferença em termos de conteúdo; a diferença na forma é sempre essencial. A realidade efetiva é o estar interessado em existir nela". Nela, encontramos a reafirmação da distinção que começa na frase "Se é que deve haver uma diferença [...]", pois, 
colocada por Kierkegaard não foi bem interpretada por Simons, fazendo-o passar despercebido pelo papel que o sujeito ocupa nessa equação que envolve pensar, agir e subjetividade.

Agora que julgamos ter demonstrado a relevância da noção de um sujeito/ subjetividade para a determinação de desinteresse do pensamento por Kierkegaard naquela passagem, nos dando sentido à distinção pensamento-ação, podemos ver por que ele, logo depois, fala de "um pecado no pensado" [en Synd $i$ Tanke] num confinium. Conforme interpretamos, o que Kierkegaard está fazendo alii é a sua explicação da transição da ação pensada à ação efetiva, ou do pensamento à ação; transição, essa, que podemos dividir em três partes. Vejamos:

a) "Quando assim eu penso que hei de fazer isto ou aquilo, este pensamento por certo ainda não é uma ação e é qualitativamente diferente disso por toda a eternidade, $[\ldots]^{\prime \prime}$;

b) "[...] mas ele é, contudo, uma possibilidade na qual já se reflete o interesse da realidade efetiva e da ação. Por isso, desinteresse e objetividade estão a ponto de ser perturbados, porque a efetividade e a responsabilidade querem apoderar-se deles. (Dá-se assim um pecado no pensamento.)";

c) “- A realidade efetiva não é a ação exterior, mas sim uma interioridade na qual o indivíduo suspende a possibilidade e se identifica com o que é pensado, a fim de existir nele. Isso é ação".

Se analisarmos essas partes, veremos que, em ' $a$ ', temos o primeiro passo com a apresentação da ação pensada por um sujeito, i.e., Kierkegaard está fazendo referência expressa a um sujeito pensante (um 'eu' $)^{32}$. Esse pensamento é uma possibilidade a qual ele pode ou não efetivar, logo, ter pensado na ação não é ter

notemos que, nesse trecho, Kierkegaard não utiliza pensar/agir ou pensamento/ação (que pode sugerir determinações ontológicas para o pensar), mas "ação pensada" [tænkte Handling] e "ação real" [virkelige], ou seja, sinônimos que identificam o primeiro com o "pensar" e o segundo com o "agir", o que significa dizer que aquele "pensar" ou "pensamento" (da frase "Se é que deve haver uma diferença [...]") adjetivado como desinteressado é o mesmo que a "ação pensada", i.e., expressão que traz à tona o papel de um sujeito que está apenas pensado numa ação e não um atributo do próprio pensamento em si como desinteressado.

31. Estamos nos referindo, especificamente, a essas linhas: "Quando assim eu penso que hei de fazer isto ou aquilo, este pensamento por certo ainda não é uma ação e é qualitativamente diferente disso por toda a eternidade, mas ele é, contudo, uma possibilidade na qual já se reflete o interesse da realidade efetiva e da ação. Por isso, desinteresse e objetividade estão a ponto de ser perturbados, porque a efetividade e a responsabilidade querem apoderar-se deles. (Dá-se assim um pecado no pensamento.) - A realidade efetiva não é a ação exterior, mas sim uma interioridade na qual o indivíduo suspende a possibilidade e se identifica com o que é pensado, a fim de existir nele. Isso é ação". (2016, p. 56/ SKS7, p. 310).

32. Evidenciando-nos, novamente, que o propósito da distinção entre pensamento e ação, feita duas frases antes, tem por finalidade suas relações com o sujeito, muito mais que por questões ontológicas. 
agido. Assim, extraímos três elementos de 'a': 1) um sujeito pensando ou usando do pensamento, 2) uma ação pensada qualitativamente diferente da ação e 3) um sujeito que pensa antes de agir. Já em ' $b$ ', surge, propriamente, o caráter subjetivo frente o pensamento que o próprio sujeito tem, i.e., o pensamento (que é neutro ou desinteressado porque não pode ter interesse por si) é articulado em vista da ação, com interesse pelo sujeito. Aqui é visível aquela distinção, que fizemos anteriormente, no uso do termo 'pensamento' (enquanto ele mesmo e enquanto produto do sujeito ou algo pensado) através da maneira com que Kierkegaard usa as determinações do pensamento, fazendo uma combinação que parecia não possível caso ele fosse analisado apenas ontologicamente, i.e., Kierkegaard diz, primeiro, que aquele pensamento (ação pensada) é uma possibilidade (característica ontológica relacionada à Realitet, contrária à Virkelighed) e, em segundo, que nele se reflete o interesse da subjetividade - ou seja, um pensamento que é possível e interessado. Logo, se víssemos essa afirmação apenas pelo prisma ontológico, uma contradição estaria presente, pois, poucas linhas acima, Kierkegaard afirmou que o pensamento é também desinteressado - assim, como ele poderia, agora, afirmar interesse no pensamento possível, desinteressado e objetivo? Entretanto, desde que acompanhemos a distinção que propomos, essa contradição é somente aparente porque a determinação de desinteresse tem sua base na subjetividade (presente no 'pensamento enquanto ele mesmo' simplesmente pela falta de uma subjetividade em si). Ou seja, em ' $b$ ', temos que o sujeito tira o pensamento da sua neutralidade inerente ao começar a refletir a sua própria subjetividade através do tipo de reflexão que é a da interioridade - o status de possibilidade ainda não desapareceu, mas o desinteresse e a objetividade do pensamento começam a perder espaço por conta do sujeito ser subjetivo (aqui começa a se evidenciar aquela mudança qualitativa operada pelo sujeito). É aí, então, que a subjetividade, em se aproximando daquela possível ação (apenas pensada), faz "um pecado no pensamento" por ele deixar de ser neutro e passar a ser um pensamento interessado e subjetivo do pensador subjetivo. Quando ocorre, então, a identificação por meio da aderência subjetiva naquele conteúdo pensado depois da deliberação, com o intuito de se existir nele - transformando possibilidade em efetividade -, uma ação é realizada ${ }^{33}$ (que é a descrição que temos em ' $c$ '). Portanto, a subjetividade, nessa passagem da ação pensada à ação efetiva, altera completamente a ontologia do pensamento que ela pensou (com relação às ações fortes, é claro) porque o pensamento, através dela, deixa de ser possível para ser efetivo na ação, desinteressado para ser interessado, e objetivo para ser subjetivo.

Com base no trecho ' $b$ ' que vimos acima, onde Kierkegaard fala, claramente, de um pensamento que o sujeito teve, que não é a ação, e que já reflete o interesse

33. Aqui, temos a dupla tarefa da subjetividade para a ação efetiva: 1) interromper a deliberação (ou o processo de selecionar e analisar ações pensadas/possíveis) e 2) se identificar com uma delas com o intuito de existir nela, ou seja, fazer o que se pensou tendo como elo a subjetividade. 
da ação, perguntamos: já não estaria, aqui, aquilo que Simons chamou de intenção (quando apresentamos a sua crítica) e que Kierkegaard não admitiria como interessado? Se sim, nesse sentido, cabe acrescentarmos também a deliberação. Ou seja, pensar nas opções do que fazer ou deliberar e ter a intenção (no sentido colocado por Simons) já podem refletir o interesse do sujeito; Kierkegaard apenas diz que esses movimentos não são ações no sentido forte, não que elas não devam ser pensadas.

O 'pecado no pensamento', assim, é o confinium (ou fronteira onde dois lados se encostam) que Kierkegaard afirmou entre o pensamento (possível, desinteressado e objetivo do ponto de vista ontológico) e a subjetividade (interessada, subjetiva e efetiva). Esse lugar de contato, por assim dizer, é onde o sujeito pode pensar com liberdade na sua existência - só que para se chegar nesse lugar, a questão deve interessar à subjetividade; não é, dessa forma, qualquer questão que chega aí, ainda mais porque não há apenas questões de ordem subjetiva. O confinium é mais uma consequência da existência da subjetividade que um defeito no pensamento; por isso Kierkegaard admite a sua existência - ele não é uma solução rápida e mal pensada que serve para preencher um buraco ao lembrar que o sujeito pode pensar em si mesmo embora ele (o pensamento) ainda seja desinteressado, possível e objetivo. Além disso, segundo julgamos nossas observações suportarem, o 'pecado no pensamento' é aquela perturbação no pensamento que Simons afirmou Kierkegaard não ter dito, mas que apenas estava "a ponto de ser", pois, se a ação é a decisão subjetiva de escolha de uma ação pensada antes, o pensamento tem de ter sido perturbado em seu desinteresse.

Agora que analisamos a definição de ação oferecida por Kierkegaard mais detidamente, verifiquemos se ela, como afirma Simons, realmente põe como indiferente ou não importante a ação exterior ${ }^{34}$. Para nós, a posição de Kierkegaard é a contrária. De fato, o que Kierkegaard nega é que a ação externa seja o critério para a verdadeira ação (e isso porque, como já vimos, a ação exterior pode não ter nada a ver com a subjetividade). O erro de Simons, para afirmar isso, está ligado com aquilo que consideramos ser seu outro erro interpretativo: confundir o conceito de decisão com o de intenção ${ }^{35}$. Embora o juízo de Simons pareça adequado (i.e., conforme a nota de rodapé anterior, que decidir fazer algo é ter a intenção de fazêlo), é preciso mantermos a diferença em Kierkegaard - sendo que o próprio Simons notou que Kierkegaard se utiliza do termo intenção, naquelas duas páginas em que ele está analisando, uma vez e pejorativamente. A frase é a seguinte:

\footnotetext{
34. "The series of examples that follow his solution [i.e., 'A realidade efetiva não é a ação exterior, mas sim uma interioridade (...)'] are intended to show the unimportance of the mere movements that follow the decision". (SIMONS, 1976, p. 114).

35. "The decision is the action. Kierkegaard does not mention the word 'intention' except once, pejoratively. Nevertheless, his account could accommodate the concept, since to decide to do something is necessarily to come to intend to do it". (SIMONS, 1976, p. 114).
} 


\begin{abstract}
Não se nega que a realidade efetiva da ação é muito frequentemente confundida com toda sorte de representações, intenções [Forsætter], impulsos para resoluções, prelúdios de disposições de ânimo, etc., que em geral muito raramente se age; ao contrário, admite-se que isso tem contribuído grandemente para a confusão. (2016, p. 57-58/SKS7, p. 311).
\end{abstract}

Como vemos, para Kierkegaard, 'intenção' tem um sentido mais fraco que 'decisão' - apesar de que ele não fale mais sobre isso. Talvez, como hipótese, a diferença no sentido possa estar no que se admite primeiro ou se analisa por si. Por exemplo, dizer "nós temos a intenção de viajar no próximo verão" não parece tão comprometido com o 'viajar' como em "nós decidimos viajar no próximo verão", mesmo que pareça adequado, depois de afirmarmos a segunda frase, dizer a primeira (como foi o sentido usado por Simons). Ou seja, ao dizermos a primeira frase, não temos garantido que uma decisão tenha sido tomada (i.e., não implica a segunda frase), enquanto que, ao assumirmos a segunda frase, a primeira poderia ser dita sem problemas. Mas também vejamos, num outro aspecto - agora com o que parece ser uma distinção mais precisa - uma alternativa a essa diferença no exemplo kierkegaardiano do levita arrependido. Será que o levita não poderia usar os dois termos numa mesma frase sem que tivessem o mesmo sentido? Isto é, não poderia o levita dizer, ao voltar pelo caminho e não encontrar mais a vítima, que a sua intenção de auxílio não foi bem sucedida, enquanto que a sua decisão de auxiliar em nada sofreu com isso? Se há essa diferença, não podemos identificálos. Porém, agora, esse exemplo nos leva à outra consideração: ter tido a intenção de ajudar não é um resultado visível da decisão? Nesse caso, parece que sim - mas já notemos que aceitarmos ela como 'resultado' já não é identificarmos as duas. Todavia, também poderíamos encontrar a resposta contraria a essa pergunta, i.e., "não". - Por quê? - Porque é possível admitirmos que hajam, ao contrário da hipótese do levita que demos acima, intenções não similares qualitativamente às decisões, ou seja, alguém que tem a intenção de fazer algo bom com finalidade egoísta (sendo essa finalidade o primeiro passo, portanto, a decisão de conquistar algo para si). Nesse caso, a intenção, é justo admitir, pode mascarar a decisão e, aqui, nós não precisaríamos seguir a linha de Simons: ter a intenção de fazer algo bom é ter se decido a fazê-lo (porque a decisão foi a de obter "benefício" a si próprio, e a intenção "ajudar alguém").

Conquanto tenhamos dito mais que Kierkegaard nesse quesito (o que, talvez, possa ser um problema), isso nos ajuda a perceber que intenção, de diferentes formas, não é o mesmo que decisão. E, aqui, notamos cinco diferenças específicas: 1) ter a 'intenção de' é mais fraco que 'decidir que', pela possibilidade de termos intenções sem, ainda, termos nos decidido; 2) como consequência da anterior, a intenção fica no campo do possível, no campo do pensamento e, por isso, podemos dizer que as 
intenções têm a ver com o futuro, enquanto que a decisão com o presente ${ }^{36}$; 3) por isso, intenção e decisão tem diferenças ontológicas, sendo a intenção o possível e a decisão o efetivo; 4) a intenção pode ser considerada, quando partirmos da decisão, um resultado dela - ou seja, nem aí poderíamos identificá-las; e 5) a intenção pode não deixar evidente a decisão de um sujeito.

Assim, em decorrência da identificação de intenção com decisão, Simons erra ao interpretar esse parágrafo: "Entre a ação pensada e a ação real, entre possibilidade e realidade efetiva, não há, talvez, nenhuma diferença em termos de conteúdo; a diferença na forma é sempre essencial. A realidade efetiva é o estar interessado em existir nela". (2016, p. 57/ SKS7, p. 311). Diz ele:

What can have prompted Kierkegaard to have put forward such a truncated theory of action? One reason has already suggested itself, namely that Kierkegaard's conception of thought as disinterested and contemplative forces him to deny that in intention there is only the possibility of action, as there clearly is in deliberation. (1976, p. 115).

Mantendo a identificação feita por Simons, aqui vemos que ele julga ser a intenção/decisão algo do pensamento, que decidir é pensar, já que Kierkegaard nega que na decisão há somente a possibilidade da ação (ou seja, que a decisão é a ação) por causa do pensamento ser desinteressado; quer dizer, já que na decisão o pensamento não é desinteressado, nele há mais que a possibilidade da ação. Todavia, para Kierkegaard, como vimos, a decisão não é pensamento (como é a intenção - aquela passagem onde atentamos ao uso único do termo também salienta isso por conta dos demais termos utilizados em conjunto), mas é algo efetivo porque ela acontece na subjetividade. Lembremos do confinium tratado acima. Agora, vejamos o que Kierkegaard diz, nesse quesito, sobre a efetividade, na forma de um silogismo feito por nós:

- "O ético quer, justamente, anular o desinteresse da possibilidade, ao fazer do existir o interesse infinito". (2016, p. 33/ SKS7, p. 291).

- "A realidade efetiva é a interioridade infinitamente interessada no existir, o que o indivíduo ético é para si mesmo". (2016, p. 40/ SKS7, p. 296).

- Logo: "A realidade ética própria do indivíduo é a única realidade"37. (2016, p. 42/ SKS7, p. 298).

36. É claro que, se é viável ter primeiro uma intenção sem ter a decisão (como é no caso onde lemos primeiro "nós temos a intenção de viajar"), a intenção é presente e não futura; todavia, a questão temporal, aqui em conjunto com a modal, coloca a intenção como possível, i.e., uma modalidade ontológica de não efetividade (relacionando os termos possibilidade, pensamento e realidade [no sentido de Realitet]), ou seja, nesse caso, ter uma intenção no momento presente de conteúdo possível, num vir a ser, de uma efetividade a acontecer (por isso, futuro); já a decisão é algo que o sujeito toma no momento e torna o que foi pensado em efetivo.

37. Individets egen ethiske Virkelighed er den eneste Virkelighed. (SKS7, p. 298). 
Ao colocarmos como termo-médio "anular o desinteresse da possibilidade, ao fazer do existir o interesse infinito" e "a interioridade infinitamente interessada no existir, o que o indivíduo ético é para si mesmo", teremos a conclusão de que a realidade efetiva é a realidade ética do sujeito (que reside, obviamente, na subjetividade). Isso quer dizer que o que está nesse âmbito não é o possível, mas o efetivo; e já que a decisão acontece na subjetividade (interior, não exterior), ela é efetividade e, por isso, ação. Daí Kierkegaard dizer duas coisas que Simons parece não ter compreendido: 1) que a decisão anula a possibilidade (ou o pensamento como ação pensada) para existir nela (ou seja, torna efetiva a possibilidade); e 2) que a diferença entre a ação pensada e a efetiva está na forma e não no conteúdo, pois o conteúdo é o mesmo tendo em vista que a decisão suspendeu as outras possibilidades porque escolheu uma (i.e., identidade de conteúdo) e, como a decisão é subjetiva (que não quer dizer apenas interna, mas também interessada), quer existir nela (esse 'querer' é a forma, pois se ele não quisesse, a ação pensada continuaria como tal até uma decisão ser tomada).

Desse modo, se a decisão não é um pensamento (pois subjetiva, interessada, ética e efetiva) e ela implica na suspensão da possibilidade para existir no conteúdo do pensamento, ela deve implicar, no mínimo, alguma ação exterior, nem que seja apenas a tentativa de tal (ponto que Simons não observou ${ }^{38}$ ), pois o 'existir' é da ordem prática ${ }^{39}$. Se levarmos a sério o "estar interessado em existir" ou o "a fim de existir", depois de vermos detidamente a diferença entre ação pensada e efetiva, e não a ligarmos com o mundo exterior, a própria distinção de Kierkegaard não fará diferença. Embora seja num outro aspecto de sua crítica, Simons (1976, p. 118) coloca a pergunta se Kierkegaard continuaria a considerar o levita tão digno caso ele, mesmo com remorso, não tivesse voltado. Segundo interpretamos, Kierkegaard daria uma resposta negativa por dois motivos: 1) o remorso não é decisão; 2) se a decisão é o escolher uma ação pensada (no caso, algo como "eu vou ajudar aquela vítima") e querer existir nesse conteúdo pensado, o levita não poderia estar, de fato, querendo existir nesse conteúdo se apenas ficasse pensando nele - aqui, essa ação pensada seria sempre uma da qual o levita poderia se esquivar ${ }^{40}$. Nesse estágio da discussão, é justo recordarmos a bem conhecida distinção entre o estético e o ético já posta em 1843 na obra $\mathrm{Ou}$-Ou e mantida e retomada em sua essência no Pós-Escrito, i.e., a importância de não se ficar preso às possibilidades e, com isso, não agir (assim como o esteta), mas de escolher alguma e de a transformar em efetividade (como

38. Aqui voltamos ao ponto onde introduzimos o erro interpretativo da identificação entre decisão intenção, i.e., onde íamos discutir sobre a importância da ação exterior.

39. Talvez alguns exemplos extremos poderiam ser levantados para vermos outras possibilidades, mas julgamos que eles também teriam suas condições específicas que auxiliariam numa solução; $p$. ex., no caso da impossibilidade de movimentos externos - não podemos dizer que pessoas nessa situação não existem e nem agem (mas desconhecemos como Kierkegaard trataria esse tema).

40. A relação do indivíduo para com a ação pensada continua sempre apenas uma possibilidade da qual ele pode esquivar-se. (2016, p. 57/ SKS7, p. 311). 
o ético $\left.{ }^{41}\right)$. No Pós-Escrito, em especial, podemos ver essa diferença e implicação ao exterior quando Kierkegaard diz (2016, p 38-39/ SKS7, p. 295):

Estética e intelectualmente vale que uma realidade só é compreendida e pensada quando o seu esse [lat.: ser real] é dissolvido em seu posse [lat.: poder-ser]. Eticamente vale que a possibilidade só é compreendida quando cada posse é realmente um esse; quando o estético e o intelectual examinam, protestam contra todo esse que não seja um posse; quando o ético examina, condena todo posse que não seja um esse [...].

Se, por isso, o ético deve transformar o posse (que podemos colocar como a deliberação, a possibilidade e a ação pensada) em esse (ou o oposto de posse: decisão, efetividade e ação efetiva), dessa forma, se torna evidente a parte que cabe à ação exterior nas ações éticas. O movimento inválido a respeito da ação exterior é o de tomá-la como o critério para a ação estritamente pessoal, i.e., pretender que algo externo indique ou faça valer o que é da ordem interna; Kierkegaard, assim, não diz que a ação externa não é importante - e, muito menos, desnecessária -, mas, sim, que ela não faz da ação, a ação.

Chegamos, agora, no quinto - eúltimo que trataremos - "erro interpretativo" que pensamos Simons ter cometido; talvez esse, propriamente, não seja um erro, mas apenas uma interpretação diferente ou um outro ponto de vista. Para ele, como já vimos, assim como para nós, o conceito de ação oferecido por Kierkegaard é moldado pela sua metafísica ${ }^{42}$. Entretanto, nós discordamos no 'como', no 'que de forma isso se dá'. Relembrando: Simons, referindo-se à metafísica, vai para o problema da interação entre mente e corpo até chegar na hipótese de ocasionalismo da parte de Kierkegaard - ou seja, é uma metafísica, no fundo, porque trata de Deus e do Seu Poder sobre o mundo externo. Todavia, quanto a nós, nos referimos à metafísica como base da ação em Kierkegaard, não porque ela fala em Deus, mas porque a ontologia é uma de suas partes - mas não somente isso, mais propriamente, conforme julgamos, a ação está tanto em um contexto tanto ontológico quanto epistemológico ${ }^{43}$. A justificativa de nossa posição é simples: a ação, identificada como a decisão na interioridade, está dentro do campo da ética ${ }^{44}$, e a ética - junto da religião, para Kierkegaard - é assunto da verdade subjetiva, e essa, por sua

41. Lembremos do Juiz Wilhelm (1987, p. 170/ SKS3, p. 166) quando diz que se sacrifica pela sua obra, mulher e filhos; esse tipo de posição e escolha para uma vida ética não pode significar ausência de ação exterior.

42. "In other words his philosophy of action is shaped by his metaphysics, and forms part of it". (1976, p. 117).

43. Aqui, nós não iremos discutir com Simons a respeito daquele rastreamento - que, de fato, mostra a sua pertinência para um estudo particular - que o leva ao problema da interação sujeito-mundo efetivo, mas, sim, focar no como a ação também está fazendo parte da metafísica kierkegaardiana em outro sentido (ontológico e epistemológico).

44. Recordemos que a ética é tratada, sobretudo, nos dois parágrafos do terceiro capítulo da seção dois da segunda parte, e a ação está aí presente. 
vez, tem sua origem como alternativa ao conceito clássico de verdade - visto como falho no Pós-Escrito por questões ontológicas, a saber, a partir da diferença entre ser e pensar ${ }^{45}$. Logo, a ação efetiva ou ação estritamente pessoal (única preocupação de Kierkegaard) tem suas raízes no problema ontológico da distinção entre ser e pensar, pois é através dela que Kierkegaard nega o conceito clássico de verdade, abre espaço para a subjetividade - que continua a se perguntar sobre a verdade ${ }^{46}-\mathrm{e}$ encontra como matéria para ela tanto a ética quanto a religião/fé.

Esse fato é relevante, principalmente, porque sendo a ética parte da verdade subjetiva, isso quer dizer que ela cabe apenas ao próprio sujeito que a pensa e não pode (ou deve) ser vista de forma objetiva. Isso se dá por conta da verdade subjetiva ser sustentada pela apropriação, interiorização do sujeito sobre o que ele reflete. Além de uma notável contrariedade com a proposta kantiana de ética (que, sabidamente, tenta objetificar as ações corretas através de fórmulas como o imperativo categórico), ela circunscreve a ação à subjetividade/interioridade, fazendo com que as observações que fizemos acerca dos erros interpretativo de Simons (ou a conceituação da ação segundo pensamos ser a adequada com o texto kierkegaardiano) ganhem um contexto de onde não devem ser retidas. Em outras palavras: o conceito de ação de Kierkegaard foi determinado para se juntar à estrutura do pensador subjetivo, i.e., serve para responder como e quando, de fato, um pensador subjetivo age.

Ao retirarmos o conceito de ação de Kierkegaard do seu contexto teórico a fim de buscarmos, através dele, uma teoria da ação que seja abrangente, naturalmente, o resultado dessa pesquisa será negativo - como foi o caso de Simons. Isso quer dizer, no fundo, duas coisas: tanto que Kierkegaard não tem uma teoria da ação nos moldes que pensamos (dado seu contexto restrito e em paralelo com a breve introdução que demos, acima, sobre a teoria da ação), quanto que o objetivo de Simons, de tentar extrair uma [teoria da ação] das obras kierkegaardianas, é indevido porque, textualmente (i.e., seu contexto teórico), elas não permitem. Esse fato se mostra evidente segundo seus erros interpretativo que, guiados pelo seu propósito no artigo, vê, nas observações de Kierkegaard, uma falha.

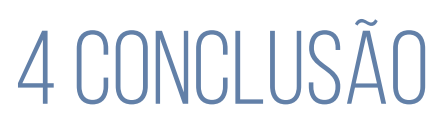

45. Excetuando-se a referência à ação, o problema da verdade e as ligações que foram feitas a ela podem ser vistas, basicamente, no 2013, p. 199-215/ SKS7, p. 173-187. E, para uma análise mais detalhada da relação entre ser e pensar em Kierkegaard, vide o artigo de Gabriel Ferreira, publicado no Kierkegaard Studies Yearbook de 2015: "The philosophical thesis of the identity of thinking and being is just the opposite of what it seems to be": Kierkegaard on the relations between Being and Thought.

46. 2013, p. 201/ SKS7, p. 175. 
Com efeito, o artigo de Simons é cuidadoso com o seu intento. Julgamos que ele tem uma boa estrutura, onde primeiro apresenta a "teoria" da ação de Kierkegaard e, depois, mostra as suas falhas, sobretudo, por não dar conta de uma série de problemas; todos os contra-argumentos que utiliza, os variados tipos de ação, são corretos, bem observados e caberiam, legitimamente, se Kierkegaard estivesse propondo uma teoria da ação. Porém, o caso é o inverso: Kierkegaard não mostra que estava fazendo uma teoria da ação - não nos termos que Simons e nós a entendemos, pelo menos. Mesmo se convencionássemos chamar o conceito de ação fornecido por Kierkegaard de uma teoria ${ }^{47}$, ela, ainda assim, deveria respeitar os limites impostos que começam, despercebidamente por Simons, na sua distinção entre o que chamamos de ações no sentido forte e ações no sentido fraco. De forma geral, o primeiro passo de Kierkegaard já é o de afirmar algo como "não estamos tratando de todas as ações, mas de especificamente uma: a do pensador subjetivo, daquele que está interessado em sua existência, que está em devir". Seria algo como uma "teoria da ação restrita ou subjetiva", que não parece ter validade e importância alguma no mundo sócio-objetivo onde precisamos atribuir responsabilidades pelas coisas que, de fato, acontecem no mundo.

No Pós-Escrito, sabidamente, o pano de fundo da discussão é a relação do sujeito com o cristianismo - que concentra, em si, uma promessa de vida eterna, mas que tem como requisito para o indivíduo o interesse infinito em sua própria felicidade, que passa pela fé em algo extremamente paradoxal (a encarnação de Deus). Mas o homem, via de regra, pode pensar e agir de forma objetiva, de uma forma que nem o verdadeiro problema do cristianismo surja para ele e nem muitos outros que envolvam a sua existência. É por conta disso, basicamente, que Kierkegaard vai desenvolver o conceito de subjetividade, unindo, a ele, outros como interioridade, interesse, apropriação, paixão, tipos de reflexão (que podem ser tanto quanto ao uso e quanto a relação com o pensamento), etc.; conceitos que abrem o horizonte para a importância do plano subjetivo no homem, para o fato de que ele não pode deixar de existir, tomar decisões, se arriscar na vida e, até, por uma vida eterna, caso tenha fé. É nesse contexto que Kierkegaard insere a ação, i.e., tendo em vista o pensador subjetivo ${ }^{48}$.

Quando se atenta a esse contexto, desaparece, por exemplo, aquele problema da ação exterior não significar a verdadeira ação; mas que é uma questão justíssima, por motivos óbvios, se confrontada com o conceito de ação no plano objetivo (que não é o interesse de Kierkegaard). Por isso, a principal conclusão que chegamos nessa investigação foi a de que Kierkegaard não tem uma teoria da ação nos moldes que hoje costumamos pesquisar; não porque ela é falha e deixa lacunas, mas porque 47. E aqui, deveríamos sair obrigatoriamente do Pós-Escrito, indo até As Obras do Amor e ao Ou-Ou, no mínimo.

48. Simons, como já vimos, observou parcialmente esse ponto sobre o plano religioso (1976, p. 116), mas falhou por querer algo que o conceito não oferece. 
o seu conceito de ação foi propositalmente montado de tal forma que faça parte de uma estrutura maior - dentro da ética e da religião -, que é a do pensador subjetivo. Retirar esse conceito do seu contexto teórico é tanto infrutífero quanto equivocado; é exigir algo que não foi proposto - ou seja, o conceito de ação, que foi desenvolvido por Kierkegaard, não pretende explicar nem todos e nem muitos níveis da ação humana, mas apenas um: aquele que pode, legitimamente, entrar no confinium do interesse subjetivo; o que está fora dele, como as ações fracas ou realizações, não é seu foco. Assim, ao que tudo indica, o início desse debate já se dá com a proposta de Simons, por ela ter um propósito diferente do buscado por Kierkegaard.

Por que, então, tentamos corrigir os erros interpretativo de Simons para chegar, igualmente, a uma solução negativa quanto à teoria da ação de Kierkegaard? - Aqui, vale distinguirmos os nossos resultados. Embora sejam conclusões negativas, elas não são as mesmas e nem são alcançadas da mesma forma. Simons, por querer testar a robustez da "teoria da ação kierkegaardiana", chega a sua insuficiência através da interpretação dos pontos tratados acima, enquanto nós, chegamos à inexistência da teoria da ação de Kierkegaard também por causa daqueles pontos, todavia, fazendo uma nova interpretação. Ou seja, enquanto Simons diz que há uma teoria da ação em Kierkegaard e que ela é fraca - não literalmente, mas o resultado é, visivelmente, esse -, nós, pelos mesmos argumentos que ele usou ao seu favor, mas sob nova interpretação, chegamos numa outra resposta e mais radical - da sua não existência ${ }^{49}$. Dessa forma, nós não corrigimos a interpretação de Simons para salvar a teoria da ação kierkegaardiana do julgamento de precariedade, mas algo diferente: mostrar a sua inexistência porque o conceito de ação, em Kierkegaard, tem um contexto teórico próprio, bem específico e proposital.

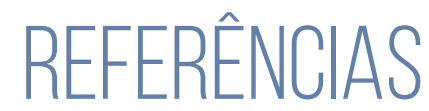

BÍBLIA. Português. Bíblia sagrada. Tradução dos textos originais, com notas, dirigida pelo Pontifício Instituto Bíblico de Roma. São Paulo: Paulinas, 1976.

DESCOMBES, Vicent. L'action. In: KAMBOUCHNER, Denis (Org.). Notions de philosophie - tome II. Paris: Gallimard, 1995, p. 103-174.

49. Falar sobre ação e dar uma definição sobre ela, não significa haver ou ter desenvolvido uma teoria da ação. Quando dizemos de sua não existência, devemos ter em mente tanto o que é propor uma teoria desse tipo quanto o intento de Kierkegaard. Não estamos dizendo, com isso, que não haja um conceito de ação em Kierkegaard e que ele é insignificante; pelo contrário: há e é importante. Mas dizer, daí, uma teoria da ação e analisá-la, chegando-se ao resultado positivo ou negativo, parece um passo ilegítimo. O problema não é a investigação - ela poderia ocorrer como experimento mental, como hipótese de trabalho: "Será que Kierkegaard tem uma teoria da ação? Dos elementos contidos nos textos, podemos derivar uma teoria da ação?". Mas isso é diferente de dizermos: "Kierkegaard tem uma teoria da ação e ela é insuficiente por tais e tais motivos". 
EMMANUEL, Steven M.; MCDONALD, William; STEWART, Jon. (Org.). Kierkegaard Research: Sources, Reception and Resources - Kierkegaard's Concepts - vol. 15 - Tome I: Absolute to Church. Surrey: Ashgate, 2013.

FERREIRA, Gabriel. "The philosophical thesis of the identity of thinking and being is just the opposite of what it seems to be": Kierkegaard on the relations between Being and Thought. In: SCHULZ, Heiko; STEWART, Jon; VERSTRYNGE, Kal (Ed.). Kierkegaard Studies Yearbook. New York: de Gruyter, 2015, pp. 13-31.

KIERKEGAARD, S. A. Afsluttende uvidenskabelig Efterskrift. Redação de Niels Jørgen Cappelørn, Joakim Garff, Johnny Kondrup, Jette Knudsen e Alastair McKinnon. Copenhagen: Søren Kierkegaards Skrifter, 2013. Livro eletrônico, não paginado. Disponível em: http://sks.dk/AE/txt.xml acesso em: 1 dez. 2017.

. Concluding Unscientific Postscript. Tradução de Howard V. Hong e Edna H. Hong. Princeton, New Jersey: Princeton University Press, 1992, vol. 1. KW vol. 12.1. . Either/Or 2. Tradução de Howard V. Hong e Edna H. Hong. Princeton, New Jersey: Princeton University Press, 1987. KW vol. 4.

. Pós-Escrito Conclusivo Não Científico às Migalhas Filosóficas: Coletânea MímicoPatético-Dialética, Contribuição Existencial, por Johannes Climacus. Tradução de Álvaro L. M. Valls. Petrópolis, RJ: Vozes; Bragança Paulista, SP: Editora Universitária São Francisco, 2013. Vol. I. (Coleção Pensamento Humano).

. Pós-Escrito Conclusivo Não Científico às Migalhas Filosóficas: Coletânea MímicoPatético-Dialética, Contribuição Existencial, por Johannes Climacus. Tradução de Álvaro L. M. Valls. Petrópolis, RJ: Vozes; Bragança Paulista, SP: Editora Universitária São Francisco, 2016. Vol. II. (Coleção Pensamento Humano).

SIMONS, Peter M. Kierkegaard's Theory of Action. Journal of the British Society for Phenomenology. v. 7, p. 111-122, 1976.

WILSON, George; SHPALL, Samuel. Action. In: Edward N. Zalta (Ed.). The Stanford Encyclopedia of Philosophy (Winter 2016 Edition). Disponível em: https:// plato.stanford.edu/archives/win2016/entries/action/ acesso em: 15/03/2018. 